\title{
Article \\ The Effect of Heavy Metal Pollutants on Bioluminescence Intensity of Luminous Mushrooms (Nenothopanus sp)
}

\section{Article Info}

\section{Article history :}

Received Agustus 28, 2020

Revised September 27, 2020

Accepted September 27, 2020

Published September 30, 2020

\section{Keywords :}

Metal, pollutants, bioluminescence, nenothopanus $\mathrm{sp}$

\section{Witriani Marvinatur Ihsan ${ }^{1}$, Ratnawulan $^{1^{*}}$}

Department of Physics, Faculty of Mathematics and Natural Science (FMIPA), Universitas Negeri Padang, Indonesia

\begin{abstract}
In the South Coastal Forest area, West Sumatra, a luminous mushroom with the species Neonothopanus Sp. This research was conducted with the aim of seeing the effect of heavy metals on the bioluminescence reaction of luminous mushrooms. Starting from the effect of heavy metal concentrations on the intensity and inhibition coefficient of luminous mushroom biolumination. From the measurement results, the maximum intensity value of luminous mushrooms is 499.6 au occurring at a wavelength of $505 \mathrm{~nm}$. At a wavelength of $505 \mathrm{~nm}$, visible light is produced in green. The results obtained are in accordance with observations, because the light emitted by the glowing mushroom is green. If the concentration of heavy metals is greater, the intensity of the bioluminescent fungus (Neonothopanus $\mathrm{sp}$ ) will decrease. The type of heavy metal affects the intensity of the fungus biolumination. The greatest decrease in intensity occurred in copper $(\mathrm{Cu})$ and iron $(\mathrm{Fe})$, zinc $(\mathrm{Zn})$ and lead $(\mathrm{Pb})$. If the heavy metal concentration is greater, the inhibition coefficient will be smaller. The greatest inhibition coefficient due to the presence of heavy metals occurs in copper $(\mathrm{Cu})$ then iron $(\mathrm{Fe})$, zinc $(\mathrm{Zn})$ and the smallest is lead $(\mathrm{Pb})$.
\end{abstract}

This is an open acces article under the $\mathrm{CC}-B Y$ license.

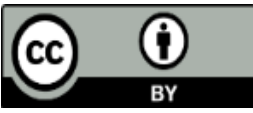

This is an open access article distributed under the Creative Commons 4.0 Attribution License, which permits unrestricted use, distribution, and reproduction in any medium, provided the original work is properly cited. (C2020 by author.

\section{Corresponding Author :}

Ratnawulan

Department of Physics, Faculty of Mathematics and Natural Science (FMIPA), Universitas Negeri Padang, Indonesia

Email : ratnawulan@fmipa.unp.ac.id

\section{Introduction}

Pollutant Is a condition that Is getting worse. This changing situation Is caused by the entry of pollutants. Pollutants generally have toxic properties (poison) which are harmful to living organisms. 
The toxicity of pollutants is what triggers pollution [1]. Environmental pollution that occurs is mostly caused by human hands. One of the environmental pollutants is heavy metal. The source of heavy metal contamination is air pollution, due to pollution caused by factory fumes and motor vehicle exhaust fumes which have reached very high levels. Pollution also occurs due to industrial activities.

According to Darmono (2001) Industrial pollutant can cause huge losses because the waste generally contains toxic substances including copper $(\mathrm{Cu})$, mercury $(\mathrm{Hg})$, chromium $(\mathrm{Cr})$, cadmium $(\mathrm{Cd})$, lead $(\mathrm{Pb})$, which are often used by an industry in the production process both raw materials, catalysts and main materials [2]. These metals will form inorganic and organic compounds that can damage living things.

Heavy metals in the air can accumulate in plants, especially plants that live freely in nature such as mushrooms. The fungus can accumulate through the air attached to the outside of the mushroom's body. Heavy metals that accumulate in obstructed mushrooms can block the light emitted by the fungus. Heavy metals attached to mushroom plants can cause a decrease in the light intensity of the fungus. The decrease in light intensity, luminous, physical properties possessed by each heavy metal, namely the concentration of heavy metals.

Mushrooms are non-chlorophyll microorganisms, in the form of hyphae or eukaryotic single cells, cell walls of chitin or cellulose that produce sexually or asexually. In the life of the world, mushrooms are a separate kingdom because the way they get their food Is different from other eukaryotic organisms, namely through absorption [3]. Mushrooms are one of the least studied life forms in the world and there are hundreds of species left that can be found in the form of bioluminescence.

Mushrooms are one of the least studied life forms in the world and there are hundreds of species left that can be found in the form of bioluminescence. Bioluminescence is a phenomenon that emits natural light emitted by organisms that may exist, there are 71 out of 100,000 species in the fungal kingdom [21]. Bioluminescent mushrooms are also found in wood or leaves that rot at night. Thus, this phenomenon is called a campfire or glowing wood. The number of luminous mushroom species recorded in 2016 was more than 80 [22].

The history of bioluminescence in mushrooms has been known for a long time by Aristotle in his early writings (384 - 322 BC) which emit light with different colors [23]. Bioluminensis comes from the word bio which means life and luminens which means emission of light. Luminense is a phenomenon where matter emits light in the visible light range [24].

Luminous mushrooms can only emit light for a certain period of time during their life cycle and the light emitted by the mushroom will start to dim until finally extinguished [28]. The physical characteristics of bioluminescence in mushrooms can be applied in various fields, such as biosensors, and biomedicine [29]. In the biosensor field, bioluminescence in mushrooms is used to monitor environmental pollution and extraction of heavy metals. In the biomedical field it is used in cancer treatment [30].

Bioluminescence Is a biological process in which light Is generated and emitted by living organisms resulting from chemical reactions in the organism's body. This phenomenon of light emitting as a result of a chemical reaction is called chemiluminescence. When this happens to living things, it Is called bioluminescence [4]. The mechanism behind this phenomenon Is an oxygendependent reaction involving a substrate commonly called luciferin, which is catalyzed by one or more various unrelated enzymes called luciferases.

Bioluminescence reactions vary widely among organisms but can be generally described as luciferase, the catalytic production of oxygen and luciferin which emits light when it returns to its 
ground state [25]. In addition, the principles of bioluminescence have been applied in many scientific fields such as agriculture, biology, ecology, and medicine [26]. Bioluminescent organisms use their light, which has various colors, periodic patterns, and intensities, for self-defense against predators, camouflage, specific intra communication, or attracting mates or prey [27].

Three main components are required in the bioluminescence process, namely the luciferin, oxygen and luciferase compounds. Luciferin compounds are organic molecules present in the body of organisms that can produce light and have heat-resistant substrates [5] [6]. Luciferase functions as a catalyst for luciferin and oxygen compounds. The three main components in this bioluminescence process produce a complex reaction called a photoprotein [5]. When the chemical reaction between luciferin and luciferase is produced, the substances present in the process break down. It is produces energy called light emission [7].

Figure 1. Is a chemical reaction that occurs in mushrooms and Figure 2. is a chemical mechanism of bioluminescence in mushrooms.

$$
\begin{aligned}
\mathrm{L}+\mathrm{NAD}(\mathrm{P}) \mathrm{H}+\mathrm{H}^{+} \stackrel{\text { soluble reductase }}{\longrightarrow} & \mathrm{LH}_{2} \\
& +\mathrm{NAD}(\mathrm{P})^{+}
\end{aligned}
$$

Figure 1. Chemical Reaction of bioluminescence Mushrooms [8].

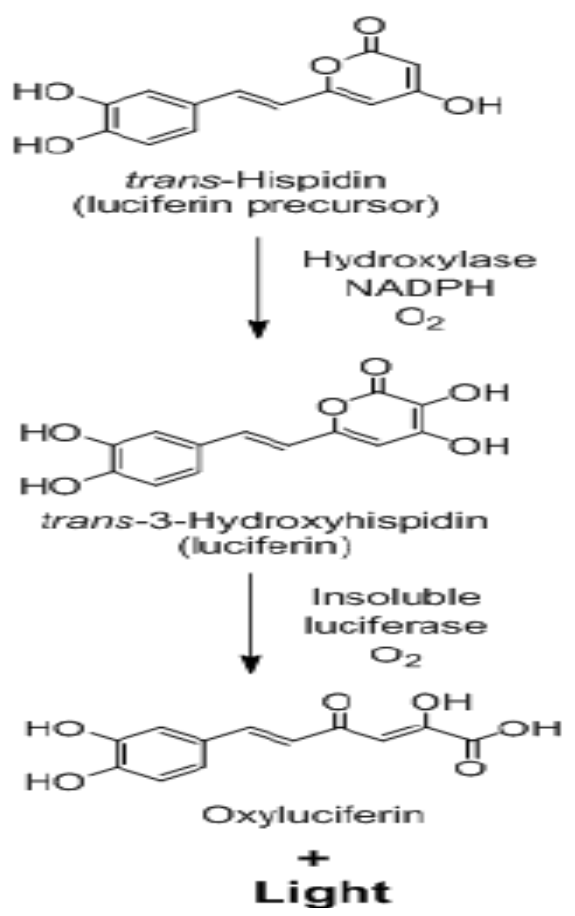

Figure 2. Chemical Mechanism of Fungal bioluminescence [9].

Figure 1 and Figure 2 describe the mechanism and reaction of bioluminescence in mushrooms, namely luciferin is added with energy, namely $\mathrm{NADH}$ and oxygen then catalyzed by the enzyme luciferase and produces oxyluciferin and light [9]. The light emission from bioluminescence mushrooms is proportional to the light emission produced by fireflies. Luminous mushrooms generally emit green light [10]. 
The addition of NADPH to the extract triggers light emission which increases sharply in intensity to reach a peak value and then gradually decreases with time reaching a relatively stable level. From this point on, the luminescence slowly weakened over the hours. Repeated addition of $\mathrm{NADPH}$ to the test did not affect light emission [20].

Bioluminescence is used for biosensor applications, mushrooms are used as indicators to monitor environmental pollution. Due to the use of biosensors with bioluminescence mushrooms, environmental pollution license can be identified faster based on the decrease in light. In biomedicine, bioluminescence mushrooms are used as a treatment for cancer [11].

The first person to observe a luminous mushroom was Aristotle in $382 \mathrm{SM}$, which emits greenish light and the wavelengths of the fungus range from $520 \mathrm{~nm}$ to $530 \mathrm{~nm}$ [11]. Mycena lucentipes mushrooms are found on damp wood surfaces and on rotting wood [12] [13]. Mycena lucentipes emit light with a wavelength of $320 \mathrm{~nm}$ [14]. The beam of light on the fungus Mycena lucentipes is used to attract insects to spread the spores of the fungus so that the fungus can breed [13].

The Luminescent Luminous Mushroom (Nenothopanus nambi) system found in tropical forests of South Vietnam, has been investigated by other researchers [15]. From these studies, it was found that the luminescence spectrum lies in the wavelength range of 480-700 $\mathrm{nm}$ (the green light wavelength). Furthermore, for bioluminescence fungi (Mycena cholorophos), the maximum intensity of this fungus is at a wavelength of $530 \mathrm{~nm}$ [16]. For the effect of heavy metals on fungi, no studies have been reported. The effect of heavy metals on bioluminescence organisms is new to fireflies. The heavy metals used are $\mathrm{Pb}, \mathrm{Zn}, \mathrm{Cu}$ and $\mathrm{Fe}$. The results showed that the lower the light emission of fireflies the greater the heavy metal concentration. This study only used flying fireflies [17]. For the luminous mushroom Mycena noctilucen species, the maximum intensity is at a wavelength of $510 \mathrm{~nm}$ with green visible light [18].

Luminous mushrooms (Nenothopanus sp) are found in many forest areas in Pesisir Selatan Regency, West Sumatra. Information on the effect of heavy metal pollutants in Padang City on the bioluminescence intensity of luminous mushrooms (Nenothopanus sp) using heavy metals copper $(\mathrm{Cu})$, iron $(\mathrm{Fe})$, zinc $(\mathrm{Zn})$ and lead $(\mathrm{Pb})$ has never been studied. For this reason, research is needed to see the effect of concentrations and types of heavy metals on the intensity of bioluminescence of luminous mushrooms (Nenothopanus sp).

\section{Experimental Section}

In this study, the tool used was the Nanophotometer N50. The sample in this study was the luminous mushroom species Nenothopanus Sp taken in the South Coastal Forest area, West Sumatra.

In this study, measurements of the wavelength and relative intensity of luminous mushrooms were measured and the inhibition coefficient value of the luminous mushroom bioluminescence. The steps taken are:

\subsection{Sample Preparation}

In this study, the sample used was the glowing mushroom species Nenothopanus Sp taken in the South Coastal Forest area, West Sumatra. This luminous mushroom is extracted from its substrate, namely dead wood. Then put in a closed container with air holes. Figure $3 \mathrm{a}$ is a sample of luminous mushrooms. 


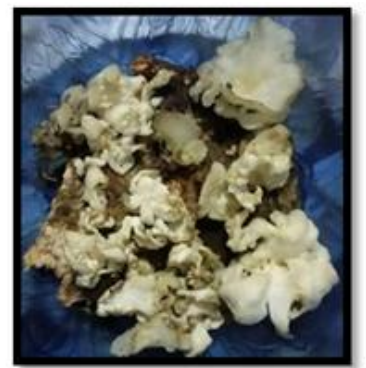

(a)

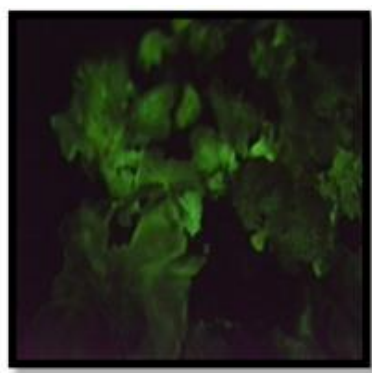

(b)

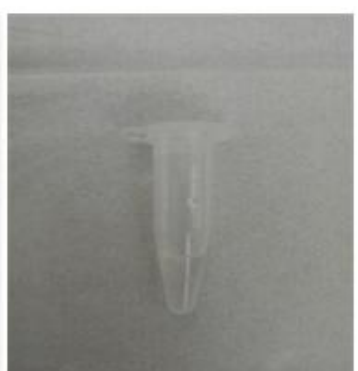

(c)

Figure 3. Sample Luminous Mushrooms Nenothopanus Sp (a); Sample Luminous Mushrooms Nenothopanus Sp while Emitting Light (b) and Mushroom Extract Nenothopanus Sp (c)

At night, the light produced by this luminous mushroom is green, like Figure $3 b$.

\subsection{Measurements Without Heavy Metal's}

Luminous mushroom extract added with NADH. The measured luminous mushrooms were the extract of luminous mushrooms obtained from the isolation of mushrooms. Glowing mushroom extract can be seen in Figure 3c. The luminous mushroom extract that had been added with NADH was inserted into the N50 nanophotometer, then measured the wavelength and relative intensity of the luminous mushrooms.

\subsection{Flow Diagram Mushroom Isolation}

The flow chart of the fungus isolation procedure can be seen in Figure 6.

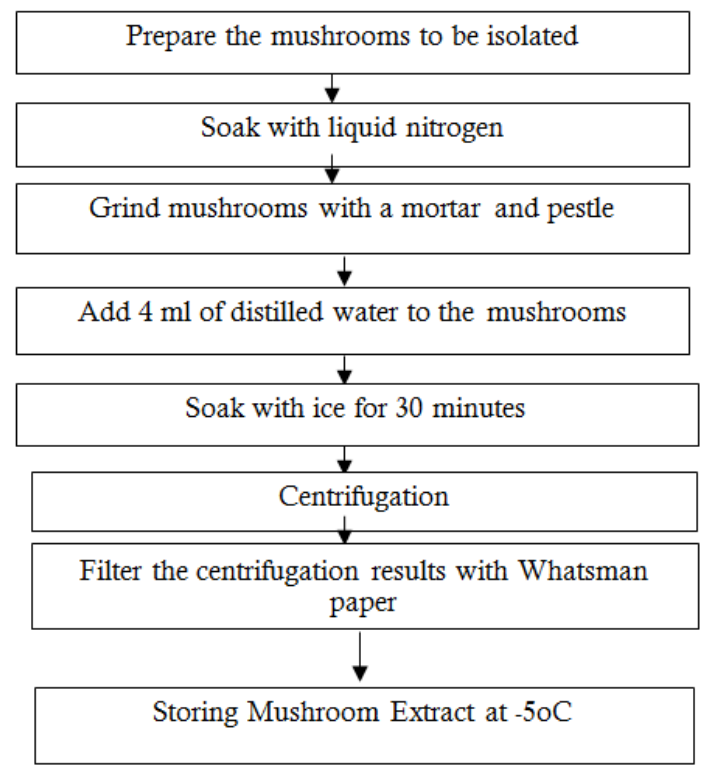

Figure 4. Flow diagram of the fungus isolation procedure to be performed

\section{Measurements with Heavy Metal's}

For measurements with heavy metals, lead $(\mathrm{Pb})$, copper $(\mathrm{Cu})$, zinc $(\mathrm{Zn})$ and iron $(\mathrm{Fe})$ were used, with heavy metal concentrations of $0.1 \mathrm{mg} / 1,5 \mathrm{mg} / 1$ and $10 \mathrm{mg} / 1$ respectively. L. 
Incorporating the heavy metal lead $(\mathrm{Pb})$, copper $(\mathrm{Cu})$, Zinc $(\mathrm{Zn})$ and Iron $(\mathrm{Fe})$ into the luminous mushroom extract, then measuring the wavelength and relative intensity of the luminous mushrooms using a nanophotometer N50.

In this measurement data is collected through physical quantities contained in the wavelength and transmittance measurement system (relative intensity). Data obtained directly from the results of measurements of wavelength and relative intensity based on variations in heavy metal concentrations.

Data processing techniques were carried out to determine the effect of the type of heavy metal and dust concentrations on the inhibition coefficient of bioluminescence of luminous mushrooms (Nenothopanus sp), namely:

To determine the effect of the concentration and type of heavy metal on the relative intensity of luminous mushroom bioluminescence, a data plot was carried out and analysis of the relationship between variations in heavy metal concentrations and the relative intensity of bioluminescence mushrooms.

To determine the effect of the type and concentration of heavy metal and dust concentrations on the inhibition coefficient of bioluminescence of luminous mushrooms, data plots were carried out and analysis of the relationship between variations in heavy metal concentrations to the inhibition coefficient of the relative intensity of luminous mushroom bioluminescence. To determine the inhibition coefficient can be calculated using the equation:

$$
\ln \frac{I}{I_{o}}=\mathrm{KC}
$$

$\mathrm{I}=$ the maximum intensity value of bioluminescence in the presence of heavy metal compounds

$\mathrm{I}_{0}=$ the maximum intensity value of bioluminescence without heavy metal compounds

$\mathrm{K}=$ inhibition coefficient

$\mathrm{C}=$ concentration of heavy metal compounds

\section{Results and Discussion}

Relative intensity obtained from measurements of the luminous mushroom Nenothopanus Sp without heavy metal's and with heavy metal's lead $(\mathrm{Pb})$, copper $(\mathrm{Cu})$, zinc $(\mathrm{Zn})$ and iron $(\mathrm{Fe})$, with heavy metal concentrations of $0.1 \mathrm{mg} / 1,5 \mathrm{mg} / 1$ and $10 \mathrm{mg} / 1$ using a nanophotometer can be plotted into the diagram in Figure 5. 


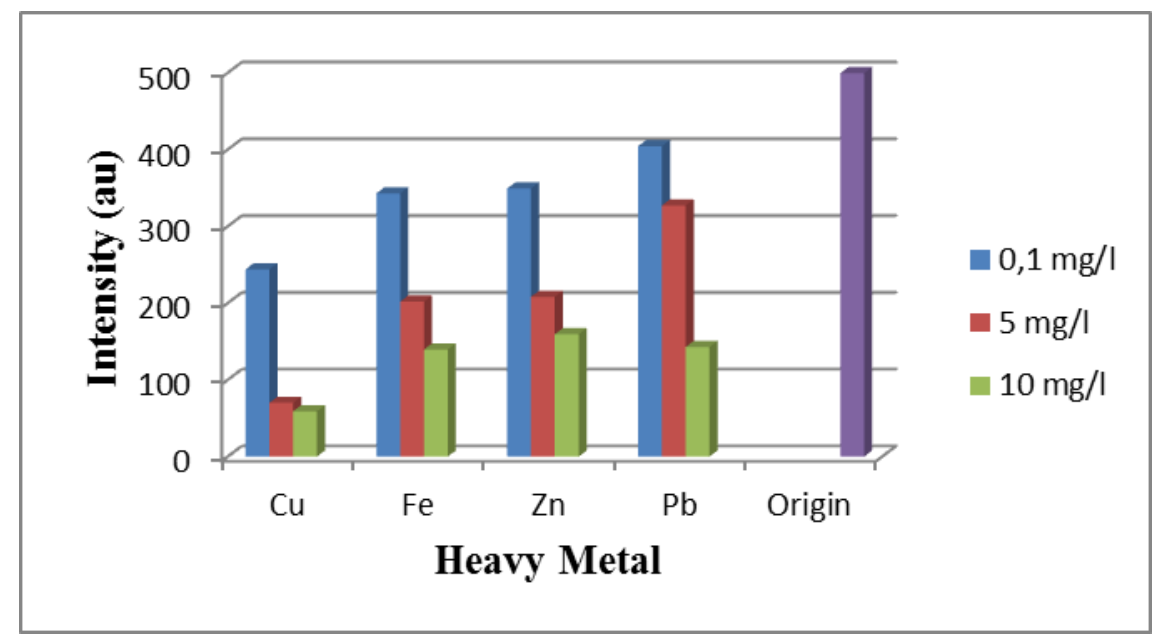

Figure 5. Graph of Relative Intensity of Luminous Mushrooms Without and with Heavy Metal's

Figure 5 shows that the relative intensity of luminous mushrooms without heavy metal's is 499.6. However after being exposed to heavy metal's, the relative intensity of luminous mushrooms decreased with increasing concentration. The sharpest decrease in relative intensity occurred in the heavy metal Copper $(\mathrm{Cu})$. In the heavy metal copper $(\mathrm{Cu})$ with a concentration of $0.1 \mathrm{mg} / 1$ the relative intensity became 243.9 , the concentration of $5 \mathrm{mg} / 1$ became 70.1 and at a concentration of $10 \mathrm{mg} / 1$ the intensity decreased to 59.0 . Iron $(\mathrm{Fe})$ at a concentration of $0.1 \mathrm{mg} / 1$, the relative intensity decreased to 343.0 , a concentration of $5 \mathrm{mg} / 1$ to 201.9 and at a concentration of $10 \mathrm{mg} / 1$ to 139.6. Zinc $(\mathrm{Zn})$ at a concentration of $0.1 \mathrm{mg} / 1$ intensity decreased to 349.4 , at a concentration of 5 $\mathrm{mg} / 1$ to 208.2 and at a concentration of $10 \mathrm{mg} / 1$ to 159.4 . Meanwhile, the relative intensity of glowing mushrooms which was influenced by the heavy metal lead $(\mathrm{Pb})$ with a concentration of 0.1 $\mathrm{mg} / 1$ decreased to 404.4 , the concentration of $5 \mathrm{mg} / 1$ became 327.2 and at a concentration of 10 $\mathrm{mg} / 1$ decreased to 142.8 .

The effect of metal concentration on decreasing light emission intensity can be seen by means of the maximum intensity value of bioluminescence in the presence of heavy metal compounds with certain concentrations can be compared with the intensity of bioluminescence without heavy metal compounds. The parameter of inhibition of bioluminescence intensity without heavy metal compounds can be calculated using equation 1 . Table 1 is the calculation of the inhibition value of the intensity of bioluminescence.

Table 1. Bioluminance Intensity Inhibition Value at Various Concentrations of Heavy Metal

\begin{tabular}{cccc}
\hline Heavy Metal & \multicolumn{3}{c}{$\left.\mathrm{K}^{-1} \mathrm{M}^{-1}\right)$} \\
\cline { 2 - 4 } & $0,1 \mathrm{mg} / 1$ & $5 \mathrm{mg} / 1$ & $10 \mathrm{mg} / 1$ \\
\hline Copper & 7,17 & 0,393 & 0,2137 \\
Iron $(\mathrm{Fe})$ & & & \\
Zinc $(\mathrm{Zn})$ & 3,78 & 0,1812 & 0,1276 \\
Lead $(\mathrm{Pb})$ & 3,58 & 0,1754 & 0,1142 \\
& 2,11 & 0,0848 & 0,1255 \\
\hline
\end{tabular}


From the data, a graph of the heavy metal lead $(\mathrm{Pb})$, iron $(\mathrm{Fe})$, copper $(\mathrm{Cu})$ and zinc $(\mathrm{Zn})$ can be plotted at a concentration of $0.1 \mathrm{mg} / 1,5 \mathrm{mg} / 1$ and $10 \mathrm{mg} / 1$ against the inhibition coefficient (M1 ), as shown in Figure 6.

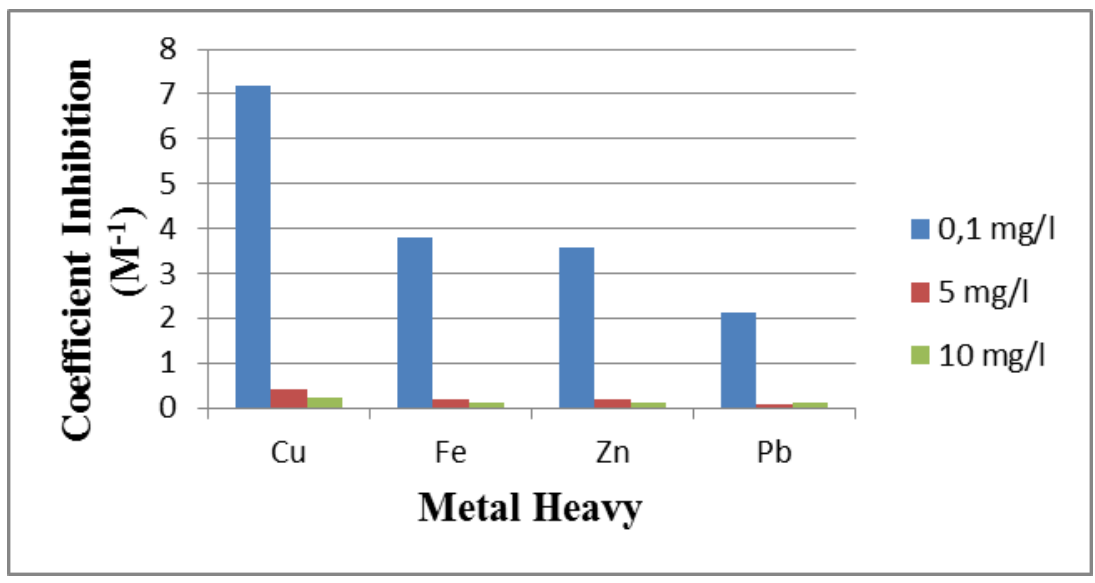

Figure 6. Diagram of the effect of heavy metal concentrations on the inhibition coefficient $\left(\mathrm{M}^{-1}\right)$ of luminous mushrooms

Figure 6 shows that the inhibition coefficient (M-1) of luminous mushrooms decreases with increasing concentration of heavy metal's. The steepest increase in the inhibition coefficient (M-1) occurred in the heavy metal copper $(\mathrm{Cu})$. At a concentration of $0.1 \mathrm{mg} / 1$ of 7.17 (M-1), a concentration of $5 \mathrm{mg} / 1$ the inhibition coefficient is 0.393 (M-1), and at a concentration of $10 \mathrm{mg} / 1$ the inhibition coefficient is 0.2137 (M-1). The inhibition coefficient of iron (Fe) at a concentration of $0.1 \mathrm{mg} / 1$ the inhibition coefficient of $3.78(\mathrm{M}-1)$ a concentration of $5 \mathrm{mg} / 1$ the inhibition coefficient of 0.1812 (M-1) and at a concentration of $10 \mathrm{mg} / 1$ the inhibition coefficient equal to 0.1276 (M-1). Zinc $(\mathrm{Zn})$ at a concentration of $0.1 \mathrm{mg} / 1$ is $3.58(\mathrm{M}-1)$, at a concentration of $5 \mathrm{mg} / 1$ the inhibition coefficient is $0.1754(\mathrm{M}-1)$, and at a concentration of $10 \mathrm{mg} / 1$ the inhibition coefficient equal to $0.1142(\mathrm{M}-1)$. Lead $(\mathrm{Pb})$ At a concentration of $0.1 \mathrm{mg} / 1$ inhibition coefficient of $2.11(\mathrm{M}-1)$, a concentration of $5 \mathrm{mg} / 1$ inhibition coefficient of 0.0848 (M-1) and at a concentration of $10 \mathrm{mg} / 1$ the inhibition coefficient of $0.1255(\mathrm{M}-1)$, while the inhibition coefficient of lead $(\mathrm{Pb})$ At a concentration of $0.1 \mathrm{mg} / 1$ the inhibition coefficient is $2.11(\mathrm{M}-1)$, the concentration of $5 \mathrm{mg} / 1$ inhibition coefficient is $0.0848(\mathrm{M}-1)$, and at a concentration of $10 \mathrm{mg} / 1$ the inhibition coefficient was $0.1255(\mathrm{M}-1)$.

To see the effect of environmental pollution concentration on decreasing light emission intensity, the maximum intensity value of bioluminescence in the presence of environmental pollution with a certain concentration can be compared with the intensity of bioluminescence without environmental pollution as shown in Figure 7. 


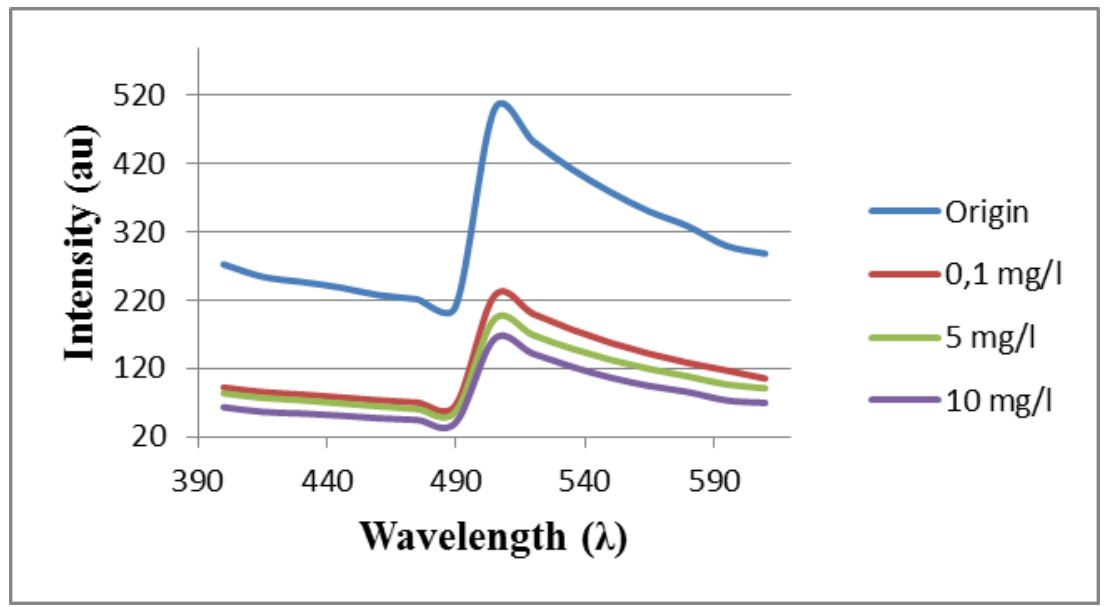

Figure 7. Graph of the relative intensity of luminous mushrooms with concentrations of $0.1 \mathrm{mg} / 1,5 \mathrm{mg} / 1$ and $10 \mathrm{mg} / 1$ in environmental pollution, namely dust.

The parameter of inhibition of bioluminescence intensity without environmental pollution can be calculated using equation 1.Calculation of the inhibition value of bioluminescence intensity can be seen in the Appendix and the results can be seen in Table 2.

Table 2. Value of inhibition of bioluminescence intensity on environmental pollution

\begin{tabular}{|c|c|c|c|}
\hline \multirow{2}{*}{$\begin{array}{l}\text { Environmental } \\
\text { pollution }\end{array}$} & \multicolumn{3}{|c|}{$\mathrm{K}\left(M^{-1}\right)$} \\
\hline & $0.1 \mathrm{mg} / 1$ & $5 \mathrm{mg} / 1$ & $10 \mathrm{mg} / 1$ \\
\hline Dust & 7,0 & 0,2 & 0,1 \\
\hline
\end{tabular}

From the data, a graph of dust can be plotted at a concentration of $0.1 \mathrm{mg} / 1,5 \mathrm{mg} / 1$ and 10 $\mathrm{mg} / 1$ against the inhibition coefficient (M-1), as shown in Figure 10.

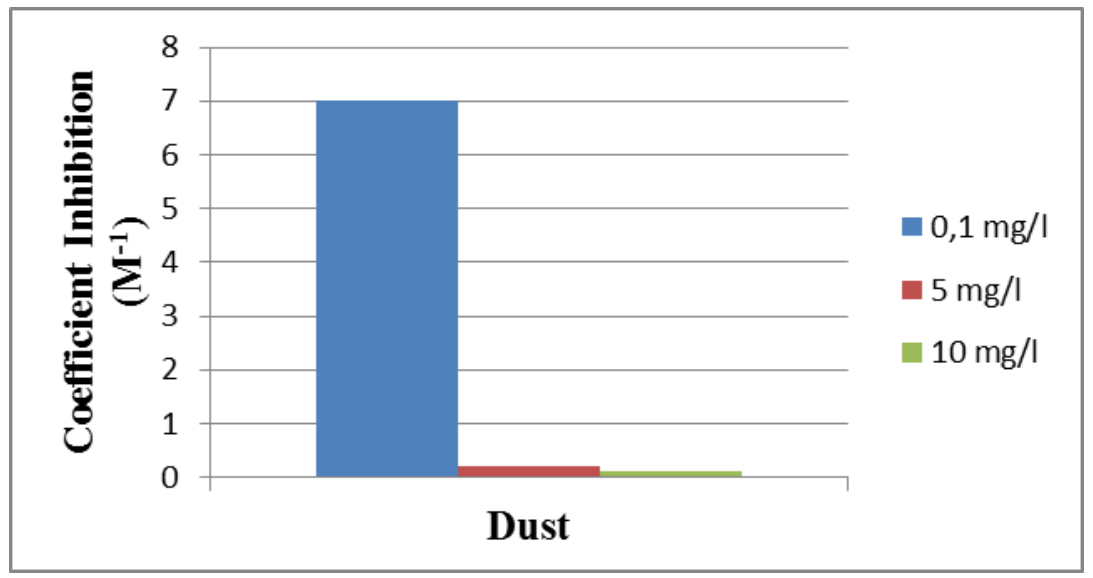

Figure 8. Diagram of the effect of dust concentration on the inhibition coefficient $\left(\mathrm{M}^{-1}\right)$ of luminous mushrooms 
Figure 8. it can be seen that the inhibition coefficient (M-1) of luminous mushrooms decreases with increasing concentration of environmental pollution, namely dust. Dust inhibition coefficient at a concentration of $0.1 \mathrm{mg} / 1$ is $7.0(\mathrm{M}-1)$ a concentration of $5 \mathrm{mg} / 1$ inhibition coefficient is 0.2 (M1 ) and at a concentration of $10 \mathrm{mg} / 1$ the inhibition coefficient is $0.1(\mathrm{M}-1)$.

Based on data analysis, it was found that the maximum relative intensity of luminous mushrooms without the influence of heavy metal's was at a wavelength of $505 \mathrm{~nm}$. The wavelength value of $505 \mathrm{~nm}$ is at the wavelength of visible light in green. This corresponds to the color that can be seen with the naked eye on the luminous mushroom.

The relative intensity of glowing mushrooms occurs due to the presence of a specific enzyme called luciferase. Luciferase enzyme which catalyzes the lucifer compound. The measurement value of the maximum relative intensity of luminous mushrooms at a wavelength of $505 \mathrm{~nm}$ was obtained at 499.6 .

The relative intensity of luminous mushrooms will change if there is an external influence, namely heavy metal's. According to Ratnawulan (2008) heavy metal's have an effect on decreasing the intensity of light emission. The presence of a toxic substance can affect enzyme activity. Toxic compounds such as heavy metal's have the ability to bind to enzymes, so that the luciferase enzyme present in glowing mushrooms is blocked from their work. The more concentrations of heavy metal's that accumulate in the body of the glow mushroom, the relative intensity of the light will decrease. From the measurement of the four types of heavy metal's, it can be seen that copper $(\mathrm{Cu})$ has the greatest decrease in intensity, then iron $(\mathrm{Fe})$, zinc $(\mathrm{Zn})$ and lead $(\mathrm{Pb})$. Heavy metal with a concentration of $10 \mathrm{mg} / 1$ has the effect of decreasing the relative intensity the greatest.

The inhibition coefficient value obtained from the decrease in light emission intensity, namely the maximum intensity value of bioluminescence in the presence of heavy metal compounds with a certain concentration can be compared with the intensity value of bioluminescence without heavy metal compounds. From the inhibition coefficient values of the four types of heavy metal's obtained, it can be seen that copper $(\mathrm{Cu})$ has the greatest inhibition coefficient value then iron $(\mathrm{Fe})$, zinc $(\mathrm{Zn})$ and lead $(\mathrm{Pb})$.

The decrease in the relative light intensity of the fungus is also influenced by environmental pollution such as dust. The experimental results regarding the effect of dust on the light emission intensity of the fungus can be seen in Figure 8. It can be seen that the relative light intensity of the bioluminescence reaction of luminous mushrooms decreases when contaminated with dust. This is because the energy in the glow of the mushroom body begins to decrease when contaminated with dust.

\section{Conclusion}

Based on the research conducted by researchers, it can be concluded that: The wavelength and intensity of biolumination of luminous mushrooms (Neonothopanus sp) before being exposed to heavy metals, namely the maximum biolumniscence intensity of 499.6 au occurred at a wavelength of $505 \mathrm{~nm}$. The large effect of heavy metal concentrations on the intensity of bioluminescence of luminous mushrooms (Neonothopanus sp) is that if the concentration of heavy metals is greater, the intensity of biolumination will decrease.

The type of heavy metal affects the intensity of the mushroom bioluminescence. The greatest decrease in intensity occurred in copper $(\mathrm{Cu})$ and iron $(\mathrm{Fe})$, zinc $(\mathrm{Zn})$ and lead $(\mathrm{Pb})$. If the heavy metal concentration is greater, the inhibition coefficient will be smaller. The greatest inhibition coefficient due to the presence of heavy metals occurs in copper $(\mathrm{Cu})$ then iron $(\mathrm{Fe})$, zinc $(\mathrm{Zn})$ and the smallest is lead $(\mathrm{Pb})$. 


\section{References}

1. F, Srikandi. Polusi Air dan Udara. Yogyakarta : Kanisius, 1992

2. Darmono. Lingkungan Hidup dan Pencemaran Hubungannya dengan Toksikilogi Senyawa Logam. Jakarta: UI Press, 2001.

3. Gandjar. Mikrobiologi. Bandung: PT. Remaja Rosdakarya. 2009.

4. F. Fan and Keith V. Wood. "Bioluminescent Assays for High-Throughput Screening." Assay and Drug Development Technologies 5 (1) : 127-36. https://doi.org/10.1089/adt.2006.053. 2007

5. D. E, Desjardin, Oliveira, A. G, and Stevani, C. V. Mushrooms Bioluminescence Revisited. Photochemical Photobiological Sciences. 7 : 170-182. 2008

6. G. Babu dan M. Kannan. 2002. Lightning Bugs. India : Tamil Nadu Agricultural University Coimbatore.

7. P, Brian A. MycoDigest : Bioluminescent Mushrooms. The Mycological Society of San Fransisco. 58(3) : 1-8. 2007

8. B. Etelvino, J. H. Bioluminescence: A fungal nightlight with an internal timer. Current Biology,25 (7), R283-R285. https://doi.org/10.1016/j.cub.2015.01.004, 2015

9. K. Teranishi.. Bioluminescence: Chemical Study on Visible Light Emission from Fungal Mycelium and Fruiting Body. 3 : 1-4., 2018

10. AG. Oliveira, Stevani CV, Waldenmaier HE, Viviani V, Emerson JM, Loros JJ, Dunlap JC. Circadian control sheds light on fungal bioluminescence. Current Biology 25, 1-5., 2015.

11. Ilondu E.M., and Okiti, A.A. Biolumininescence In Mushroom And Its Application Potensial. Nigerian Journal of Science and Environment. Vol. 14 (1). 132-139., 2016.

12. C.V, Stevani, Oliveira. Theenzymatic nature of fungal bioluminescence. Photochem. Photobiol. Sci. 8, 1416-1421., 2009

13. C.V. Stevani, Oliveira, A.G, Mendes, L.F, Ventura, F.F, Waldenmaier, H.E, Carvalho, R.P, and Pereira, T.A.. Current status of research on fungal bioluminescence: biochemistry and prospects for ecotoxicological application. Photochem.Photobiol. 89, 1318-1326., 2013

14. A.G. Oliveira, and Stevani, C.V. The enzymatic nature of fungal bioluminescence. Photochem. Photobiol. Sci. 8, 1416-1421. 2009.

15. V. S. Bondar, Puzyr, A. P., Purtov, K. V., Medvedeva, S. E., Rodicheva, E. K., \& Gitelson, J. I. 2011. The luminescent system of the luminous fungus Neonothopanus nambi. Doklady Biochemistry and Biophysics, 438(1), 138-140. https://doi.org/10.1134/S1607672911030082

16. M .Kenichi, Kojima Satoshi, Maki S Shojiro, Hirano Takashi, \& Niwa Haruki. Bioluminescence characteristics of the fruiting body of Mycena chlorophos. Luminescence, 26(6), 604-610. https://doi.org/10.1002/bio.1280, 2011.

17. M. Sarvida\& Gusnedi, R. Pengaruh Logam Berat Terhadap Sifat Fisis Pemancaran Cahaya dari Bioluminisensi Kunang-kunang ( Pteroptyx tener ). 2, 107-114. 2013

18. Z. Fajmi Marlina dan Ratnawulan. Karakteristik Fisis Bioluminisensi Jamur (Mycena Noctulicens) Dari Labuak Labu, Dhamasraya, Suamtera Barat. Pillar Of Physics. 2019.

19. Ratnawulan. Fisika Bioluminisensi Studi Kasus pada Baktei Photobacterium Phosporeum. Padang : Universitas Negeri Padang Press. 2008

20. A. P. Puzyr, Andrey E. Burov, Svetlana E. Medvedeva, Olga G. Burova \& Vladimir S. Bondar. Two forms of substrate for the bioluminescent reaction in three species of basidiomycetes, Mycology, 10:2, 84-91, DOI: 10.1080/21501203.2019.1583688, 2019.

21. V., Kushwaha and Hajirnis Sarita. A Review on Bioluminescent mushrooms: A Torch of Curiosity. Int. J. of Life Sciences, Special Issue, A7. 107 - 110. 2016. 
22. D. E., Desjardin, Perry, B. A., \& Stevani, C. V. New luminescent mycenoid mushrooms (Basidiomycota, Agaricales) from São Paulo State, Brazil. Mycologia, 108(6), 1165-1174. https://doi.org/10.3852/16-077, 2016.

23. W., Philip, Steven Delean, Tom Wood, and Andrew D Austin. Bioluminescence in the ghost fungus Omphalotus nidiformis does not attract potential spore dispersing insects, 7(2): 229-234. doi:10.5598/imafungus.2016.07.02.01. 2016.

24. H., Jorma. Persistent Luminisensi Beats the Afterglow:400 Years of Persistent Luminisensi. Electrochemical Society Interface,42-45. 2009

25. K., Tim and Kate, D.L. Umbers. 2016. Quick guide Bioluminescence: Current Biology. Vol 26. R307-R318. 2009

26. Y. Oba, Schultz DT. 2014. Bioluminescence: fundamentals and applications in biotechnology. 1. Springer-Verlag Berlin Heidelberg, Germany p. 4-14.

27. E. Esimbekova, 2014. Bioluminescence: fundamentals and applications in biotechnology. 1. Springer-Verlag Berlin Heidelberg, Germany pp. 67-197.

28. O. Shimomura, "Bioluminescence: chemical principles and methods," Singapore, World publishing Company, Public liability company limited, p.470, 2006.

29. J. G. Bundy, "Application of bioluminescence-based microbial biosensors to the ecotoxicity assessment of organotins,"pp. 353-358, 1997.

30. M. Brock, "Application of bioluminescence imaging for in vivo monitoring of fungal in fections," International Journal of Microbiology, 2012. https://doi.org/10.1155/2012/956794 